\title{
PRINSIP-PRINSIP/HUKUM PERKEMBANGAN PESERTA DIDIK DAN IMPLIKASINYA TERHADAP PENDIDIKAN
}

\author{
Mukhlis \\ Penulis adalah Dosen STAISAR. (Sekolah Tinggi Agama Islam syekh Abdur \\ Rauf) Aceh singkil
}

\begin{abstract}
Abstrak
Development is the process of change in growth at a time as a function of maturity and interaction with its environment. In other words, development is a functional change that is influenced by the achievement of the level of physical maturity. This development process can be understood by the existence of several principles / laws, in which the principle / law governs the whole of the development process and is definitely something that is in the development process. Thus, these principles must be understood by all education stakeholders, especially for School Principals and Teachers, because the principles are very urgent in increasing the effectiveness and efficiency of achieving educational goals, including by developing a curriculum or making learning programs that are in accordance with the developmental stages of participants the student.
\end{abstract}

Kata Kunci: Prinsip/Hukum, Perkembangan, Peserta didik, Pendidikan

\section{PENDAHULUAN}

Manusia dalam kedudukannya sebagai peserta didik haruslah ditempah sebagai pribadi yang utuh, yakni manusia sebagai kesatuan sifat makhluk hidup individu dan sosial, sebagai kesatuan jasmani dan rohani dan sebagai makhluk Tuhan yang harus menempatkan hidupnya di dunia sebagai persiapan menuju akhirat.

Pendidikan adalah upaya membentuk suatu lingkungan untuk anak yang dapat merangsang perkembangan potensi-potensi yag dimilikiya dan akan membawa perubahan yang diinginkan dalam kebiasaan sikapnya. Jadi, peserta didik tersebut akan dibantu oleh guru, orangtua dan orang dewasa lainya untuk memanfaatkan kapasitas dan potensi yang dibawanya dalam mencapai pertumbuhan dan perkembangan yang diinginkannya (Sunarto \& Hartono, 2013: 246).

Dalam mencapai kematangan perkembangan peserta didik, ternyata ada banyak prisip-prinsip (hukum) yang ada dalam proses perkembangan tersebut. Prinsip tersebut harus dipahami oleh setiap pendidik ataupun pemimpin dalam pendidikan agar memudahkan pembentukan/pematangan perkembangan yang dialami oleh peserta didik dan memudahkan pendidik atau pemimpin pendidikan dalam membuat kurikulum atau program pendidikan yang nantinya sesuai dengan peserta didik. 


\section{KAJIAN TEORI}

\section{Prinsip-prinsip (Hukum) Perkembangan}

Ciri-ciri perkembangan menunjukkan gejala-gejala yang secara relatif teratur. Sehingga terjadi pola-pola perkembangan yang sistematis. Atas dasar itu, maka para ahli merumuskan prinsip-prinsip perkembangan. Prinsip-prinsip perkembangan itu kadang-kadang juga dipandang sebagai hukum-hukum perkembangan. Beberapa prinsip itu adalah:

1. Perkembangan fungsi-fungsi jasmaniah dan fungsi-fungsi rohaniah berlangsung dalam proses satu kesatuan yang menyeluruh (integral).

Prinsip ini sering disebut sebagai hukum kesatuan organis (fungsional). Prinsip ini berarti bahwa organ-organ atau fungsi-fungsi itu proses perkembangannya bukan secara sendiri-sendiri, terpisah satu sama lain. Melainkan satu dengan yang lain saling berhubungan dan bahkan saling ketergantungan. Perkembangan fungsi pikir misalnya, adalah tidak terpisahkan dengan perkembangan fungsi ingatan, fungsi fantasi, fungsi motivasi dan sebagainya, bahkan tidak terpisah dengan organ-organ jasmaniah.

2. Setiap individu mempunyai kecepatan sendiri-sendiri dalam perkembangannya.

Prinsip ini mengandung maksud bahwa perkembangan antara sejumlah anak tidaklah sama,belum tentu sama pula tingkat perkembangan yang dicapainya pada suatu saat tertentu, baik pola perkembangan seluruhnya, maupun dalam aspek tertentu dari perkembangan itu. Dengan kata lain senantiasa terdapat perbedaanperbedaan individual dalam proses perkembangan anak-anak. Prinsip ini disebut juga dengan hukum tempo perkembangan.

3. Perkembangan seorang individu, baik keseluruhan maupun setiap aspeknya, kelangsungannya tidak konstan melaikan berirama.

Ini berarti bahwa proses perkemangan itu kadang-kadang cepat, kadang-kadang lambat, atau mungkin berhenti untuk beberapa waktu. Perkembangan kemampuan berbicara sebagai suatu bentuk pekembangan misalnya, padasuatu saat cepat memperooleh kata-kata baru beserta pengertiannya dalam waktu jangka singkat, pada saat yang lain sebaliknya, dalam waktu yang lebih lama hanya mendapat penambahan sedikit ataupun tidak mendapatkan kosa kata yang lain lagi. Prinsip ini disebut juga dengan hukum irama (rithme) perkembangan.

4. Proses perkembangan itu megikuti pola tertentu. 
Prinsip ini menyatakan bahwa setiap aspek perkembangan kelangsungan mengikuti aturan yang relatif tetap, sesuai dengan perkembangan itu sendiri. Misalnya, perkembangan kecakapan berjalan, dimulai dengan berdiri sambil berpegangan selanjutnya erdiri tanpa berpegangan, melangkah sambil jatuh sampai melangkah dan berjalan seperti biasa.

5. Proses perkembangan berlangsung secara berkesinambungan Dengan prinsip ini berarti apa yang sudah dicapai pada saat-saat yang lalu merupakan bagian tak terpisahkan dengan bagian-bagian sebelumya. Oleh kareba itu, adanya periode-periode perkembangan yang diadakan adalah sekedar untuk memahami perkembangan, karena sebenarnya tidak ada perubahan yang mendadak. Prinsip ini disebut juga dengan hukum kontinuitas perkembangan.

6. Antara aspek perkembangan dengan aspek perkembangan yang lain saling berkaitan atau saling berkolerasi secara bermakna.

Dengan prinsip ini dapat dicontohkan, bahwa perkembangan kesanggupan berjalan akan berkolerasi dengan perkembangan dan pertumbuhan otot-otot, syaraf-syaraf, tulang-tulang kaki dan sebagainya. Prinsip ini dipandang sebagai hukum kolerasi perkembangan.

7. Perkembangan berlangsung dari pola-pola yang bersifat umum menuju pola-pola yang bersifat khusus.

Prinsi ini pada dasarnya menyatakan, bahwa perkembangan bermula dari "globalitas" yang dengan melalui proses berangsur-angsur semakin muncul "perincian-perincian" yang smakin beraneka ragam. Dengan kata lain perkembangan ini disebut menuju diferensiasi. Oleh karena itu disebut juga dengan hukum diferensiasi (Ahmad, 1993: 30-33).

Prinsip-prinsip (hukum) perkembangan di atas, sejalan dengan pendapat Kasiram (1993:26-27) yang menyatakan bahwa pada garis besarnya peristiwa perkembangan itu mengikuti prinsip-prinsip perkembangan sebagai berikut:

1. Perkembangan itu mengikuti pola-pola tertentu dan berlangsung secara teratur.

2. Perkembangan itu selalu menuju ke diferensiasi dan integrasi.

Dari gerakan-gerakan yang bersifat massal, berkembang menjadi gerakan-gerakan khusus dan terjadi koordinasi dan integrasi antara organ yang satu dengan yang lain. 
3. Pertumbuhan dan perkembangan tidak terjadi secara tiba-tiba, tetapi berlangsung secara berangsur-angsur secara teraur dan terus menerus.

4. Suatu tingkat perkembangan dipengaruhi oleh sifat perkembangan sebelumnya. Terlambatnya suatu tingkat perkembangan, akann menghambat pula perkembangan pada tingkat berikutnya. Sebaliknya sukses dalam suatu tingkat perkembangan akan sukses juga pada perkembangan berikutnya.

5. Perkembangan adalah hasil dari peristiwa maturation, readness, dan learning.

6. Perkembangan itu antara satu anak berbeda dengan anak yang lain,baik dalam perkembangan masing-masing organ/aspek kejiwaannya maupun cepat lambatnya perkembangan tersebut.

Selain dari beberapa prinsip-prinsip (hukum) perkembangan di atas, Syamsuddin (2004:85-86) mengemukakan ada beberapa hukum (Principles) perkembangan, yaitu sebagai berikut:

1. Perkembangan dipengaruhi oleh faktor-faktor pembawaan, lingkungan dan kematangan.

2. Proses perkembangan itu berlangsung secara bertahap (progresif dan sistematik).

3. Bagian-bagian dari fungsi-fungsi organisme mempunyai garis perkembangan dan tingkat kematangan masing-masing. Meskipun demikian, sebagai kesatuan organis dalam prosesnya terdapat kolerasi dan bahkan kompensatoris antara yang satu dengan yang lainnya.

4. Terdapat variasi dalam tempo dan irama perkembangan antar-individual dan kelompok tertentu (menurut latar belakang jenis, geografis, dan kultural).

5. Proses perkembangan itu pada taraf awalnya lebih bersifat diferensiasi dan pada akirnya lebih bersifat integrasi antar bagian dan fungsi organisme.

6. Dalam batas-batas masa peka, perkembangan atau pertumbuhan dapat dipercepat atau diperlambat oleh kondisi lingkungan.

7. Laju perkembangan anak berlangsung lebih cepat pada periode kanak-kanak daripada periode-operiode berikutnya.

Dari uraian diatas, dapat disimpulkan bahwa perkembangan itu memiliki prinsip-prinsip (hukum) yang menggambarkan secara umum bahwa perkemangan itu pastinya senantiasa mengalami seluruh poin-poin yang ada didalam prinsip-prinsip (hukum) tersebut. 
Prinsip-prinsip (hukum) itu secara umum menggambarkan bahwa proses perkembangan itu terjadi secara teratur, sitematik, bertahap dan tidak terjadi secara tiba-tiba serta dipengaruhi oleh faktor-faktor tertentu. Kemudian dijelaskan juga dalam prinip perkembangan peserta didik bahwa setiap individu mengalami perkembangan yang erbeda dengan individu lainnya dan terjadi secara diferensiasi dan integrasi.

\section{Hubungan antara Belajar dan Perkembangan}

Winkel (2005:26) menyimpulkan bahwa kaitan antara belajar dan perkembangan adalah sebagai berikut:

1. Belajar melandasi sebagian besar dari perkembangan. Yang sebagian besar meliputi perkembangan psikis/mental dalam berbagai aspekya. Sebagian kecil yaitu aspek pertumbuhan yang tidak bergantung pada usaha belajar walaupun meletakkan dasar bagi perkembangan psikis/mental.

2. Adanya tahap perkembangan tertentu, berpengaruh terhadap apa yang dapat dipelajari dan dengan cara bagaimanaharus dipelajari. Misalnya anak sebelum berusia 6 tahun, biasanya dapat belajar berbicara dua bahasa sekaligus, dan belajar secara spontan dari lingkungannya yang mengajak dia berbicara dua bahasa itu. Selanjutnya belajar semacam itu makin lama ssemakin sulit, sehingga pada umur 12 tahun keatas, anak harus belajar secara formal kalau ingin belajar berbicara dalam bahasa yang masih asing baginya. Meskipun belajar dengan rajin di sekolah, namun logatnya dalam berbicara asing itu sering berbeda dengan orang yang berbicara dalam bahasa itu sejak masih belia.

Belajar dan perkembangan merupakan dua hal yang saling berkaitan satu sama lain dan masing-masing memiliki fungsi yang saling mendukung. Belajar dalam aspek perkembangan berarti usaha yang dilakukan unnttuk mencapai tahapan-tahapan menuju arah kematangan dalam perkembangan seorang individu, sementara perkembangan dalam aspek belajar merupakan proses berlangsungnya perubahanperubahan dalam diri seseorang yang membawa penyempurnaan dalam kepribadiaannya untuk menjadi manusia yang insan kamil.

\section{PEMBAHASAN}

\section{Impilkasi Prinsip-Prinsip (Hukum) Perkembangan Terhadap Pendidikan}

Manusia pada umumnya berkembang sesuai dengan tahapan-tahapannya. Perkembangan tersebut dimulai sejak masa konsepsi hingga akhir hayat. Ketika 
individu memasuki usia sekolah, yakni antara tujuh sampai dengan dua belas tahun, individu dimaksud sudah dapat disebut sebagai peserta didik yang akan berhubungan dengan proses pembelajaran dalam suatu sistem pendidikan. Cara pembelajaran yang diharapkan harus sesuai dengan tahapan perkembangan anak, yakni memilki karakteristik sebagai berikut:

1. Programnya disusun secara fleksibel dan tidak kaku serta memperhatikan perbedaan individual anak

2. Tidak dilakukan secara monoton, tetapi disajikan secara variatif melalui banyak aktivitas

3. Melibatkan penggunaan berbagai media dan sumber belajar sehingga memungkinkan anak terlibat secara penuh dengan menggunakan berbagai proses perkembangannya (Hasbullah, 2009:57).

Aspek-aspek perkembangan peserta didik yang berimplikasi terhadap proses pendidikan akan diuraikan seperti dibawah ini :

1. Implikasi Perkembangan Biologis dan Perseptual

Secara fisik, anak usia sekolah dasar memiliki karakteristik tersendiri yang berbeda dengan kondisi fisik sebelum dan sesudahnya. Karakteristik perkembangan fisik ini perlu dipelajari dan dipahami karena akan memiliki implikasi tertentu bagi penyelenggaraan pendidikan. Proses perkembangan biologis atau perkembangan fisik mencakup perubahan-perubahan dalam tubuh individu seperti pertumbuhan otak, otot, sistem syaraf, struktur tulang, hormon, organ-organ dll, termasuk juga didalamnya perubahan dalam kemampuan fisik seperti perubahan dalam penglihatan, kekuatan otot, dan lain sebagainya. Dan diperlukan suatu cara pembelajaran yang "hidup" dalam arti memberikan banyak kesempatan kepada peserta didik untuk memfungsikan unsurunsur fisiknya, dengan kata lain, diperlukan suatu cara pembelajaran seperti ini tidak saja akan memunculkan kegemaran belajar, tetapi juga akan memberikan banyak dampak positif.

2. Implikasi Perkembangan Intelektual

Perkembangan intelektual erat kaitannya dengan potensi otak manusia, potensi otak manusia hanya tampak delapan persen sebagai pikiran sadar, sedangkan sisanya 92 persen disebut alam bawah sadar. Dari penjelasan tersebut dapat kita ketahui bahwa potensi otak manusia yang berkaitan dengan perkembangan intelektual hanya memuat delapan persen saja. Untuk itu, perkembangan intelektual pada peserta didik perlu 
dikembangkan. Proses perkembangan intelektual melibatkan perubahan dalam kemampuan dan pola berpikir, kemahiran berbahasa, dan cara individu memperoleh pengetahuan dari lingkungannya. Aktivitas-altivitas seperti mengamati dan mengklasifikasikan benda-benda, menyatukan beberapa kata menjadi satu kalimat, menghappal doa, memecahkan soal-soal matematika, dan menceritakan pengalaman kepada orang lain merupakan proses intelektual dalam perkembangan anak.

3. Implikasi Perkembangan Bahasa

Bahasa merupakan alat untuk berkomunikasi dengan orang lain. Pada dasarnya bahasa sebagai alat komunikasi tidak hanya berupa bicara, melainkan juga dapat diwujudkan dengan tanda isyarat tangan atau anggota tubuh lainnya yang memilki aturan sendiri. Bahasa sangat erat kaitannya dengan perkembangan pikiran individu tampak dalam perkembangan bahasanya, yaitu kemampuan membentuk pengertian, menyusun pendapat, dan menarik kesimpulan.

Implikasi perkembangan bahasa pada peserta didik :

a. Apabila kegiatan pembelajaran yang diciptakan bersifat efektif, maka perkembangan bahasa peserta didika dapat berjalan secara optimal. Sebaliknya apabila kegiatan pembelajaran kurang efektif, maka dapat diprediksi bahwa perkembangan bahasa peserta didik akan mengalami hambatan.

b. Bahasa adalah alat komunikasi yang paling efektif dalam pergaulan sosial. Jika ingin menghasilkan pembelajaran yang efektif untuk mendapatkan hasil pendidikan yang optimal, maka sangat diperlukan bahasa yang komunikatif dan memungkinkan peserta didik yang terlibat dalam interaksi pembelajaran dapat berperan secara aktif dan produktif.

c. Meskipun umumnya anak SD memilki kemampuan potensial yang berbedabeda, namun pemberian lingkungan yang kondusif bagi perkembangan bahasa sejak dini sangat diperlukan (Hasbullah, 2009, hal. 63)

\section{Implikasi Perkembangan Kreatifitas}

Secara umum kreativitas dapat diartikan sebagai kemampuan berfikir dan bersikap tentang sesuatu dengan cara yang baru dan tidak biasa guna menghasilkan penyelesaian yang unik terhadap persoalan. Kreatifitas merupakan suatu aktivitas otak yang terorganisasikan, komprehensif, imajinatif tinggi untuk menghasilkan sesuatu yang orisinil. Oleh karena itu, kreatifitas lebih dikatakan sebagai suatu yang lebih inovatif dari pada reproduktif. 


\section{Implikasi Perkembangan Sosial}

Manusia menurut pembawaannya adalah makhluk sosial, sejak dilahirkan, bayi sudah termasuk ke dalam masyarakat kecil yang disebut keluarga. Ketika kecil, mulanya anak-anak hanya mempunyai hak saja, didalam rumah tangga ia mempunyai hak untuk dipelihara dan dilindungi oleh orang tuanya, namun lama-kelamaan keadaanitu berubah. Anak-anak yang pada mulnya hanya mempunyai hak saja, berangsur-angsur mempunyai kewajiban. Lingkungan sosial merupakan pengaruh luar yang datang dari orang lain. Selain itu, yang termasuk lingkungan sosial ialah pendidikan. Yang dimaksud dengan pendidikan adalah pengaruh-pengaruh yang disengaja dari anggota berbagai golongan tertentu, seperti pengaruh ayah, nenek, paman, dan guru-guru. Perkembangan sosial merupakan proses belajar untuk menyesuaikan diri terhadap norma-norma kelompok, moral, tradisi atau meleburkan diri menjadi satu kesatuan yang saling berkomunikasi dan bekerja sama.

6. Implikasi Perkembangan Emosional

Emosi merupakan keadaan pada diri seseorang yang disertai warna efektif, baik pada tingkat lemah maupun pada tingkat yang luas. Contoh tentang perngaruh pengaruh emosi terhadap perilaku individu dalam pembelajaran, diantaranya adalah:

a. Memperkuat dan melemahkan semangat apabila timbul rasa senang atau kecewa atas hasil belajar yang dicapai

b. Menghambat konsentrasi belajar apabila sedang mengalami ketegangan emosi

c. Menggangu penyesuaian sosial apabila terjadi rasa cemburu dan iri hati

d. Suasana emosional yang dialami individu semasa kecilnya akan mempengaruhi sikapnya dikemudian hari

Emosi mempengaruhi cara belajar anak, yaitu : (a) menyiapkan tubuh untuk melakukan tindakan, (b) reaksi emosional apabila diulang-ulang akan berkembang menjadi kebiasaan, (c) emosi merupakan suatu bentuk komunikasi, (d) suasana emosional yang dialami individu semasa kecilnya akan mempengaruhi sikapnya dikemudian hari

\section{Implikasi Perkembangan Moral}

Moral bukan hanya memilki arti bertingkah laku sopan santun, bertindak dengan lemah lembut, dan berbakti kepada orang tua saja, melainkan lebih luas lagi dari itu. Selalu berkata jujur, bertindak konsekuen, bertanggung jawab, cinta bangsa dan sesama manusia, mengabdi kepada rakyatdan negara, berkemauan keras, 
berperasaan halus, dan sebagainya, termasuk pula kedalam moral yang perlu dikembangkan dan ditanamkan dalam hati sanubari anak-anak. Perkembangan moral anak dapat berlangsung yaitu melalui penanaman pengertian tentang tingkah laku yang benar-salah atau baik-buruk oleh orang tua dan gurunya.

8. Implikasi Perkembangan Spritual

Anak-anak sebenarnya telah memilki dasar-dasar kemampuan spritual yang dibawanya sejak lahir. Untuk mengembangkan kemampuan ini, pendidikan mempunyai peranan yang sangat penting. Oleh karena itu, untuk melahirkan manusia yang ber-SQ tinggi dibutuhkan pendidikan yang tidak hanya berorientasi pada perkembangan aspek IQ dan SQ saja. Kecerdasan spiritual adalah kecerdasan untuk menghadapi dan memecahkan persoalan makna dan nilai, yang menempatkan perilaku dan hidup manusia dalam konteks makna yang lebih luas dan kaya (Hasbullah, 2009:71-72).

Berikut ini juga merupakan beberapa implikasi prinsip-prinsip (hukum) perkembangan terhadap pendidikan, yaitu:

1. Pengembangan (penyusunan, pemilihan, penggunaan) materi, strategi, metodologi, sumber, evaluasi belajar mengajar hendaknya memperhatikan periode perkembangan peserta didik.

2. Program (kurikulum) belajar mengajar disusun secara bertahap dan berjenjang sesuai dengan tahapan prkembangan peserta didik, ketentuannya seperti:

a. Dari sederhana menuju yang kompleks.

b. Dari mudah menuju sukar.

c. Sistem belajar mengajar diorganisasikan agar terlaksana prinsip mastery learning (belajar tuntas) dan continous progress (maju berkelanjutan)

3. Sampai batas tertentu, program dan strategi belajar mengajar seyogianya dikembangkan dan diorganisasikan perlakuan (intervensi) yang dapat merangsang dan mempercepat laju perkembangan peserta didik (Syamsuddin, 2004:85).

Dalam merancang pendidikan, seorang manager pendidikan haruslah mengerti tentang proses perkembangan peserta didik dan menyesuaikannya dengan proses tersebut, hal ini sangat urgen karena untuk mengefektifkan, mengefisienkan dan memaksimalkan pencapaian tujuan dari pendidikan tersebut. 


\section{KESIMPULAN}

Ciri-ciri perkembangan menunjukkan gejala-gejala yang secara relatif teratur, hal tersebut diatur dalam prinsip-prinsip (hukum) perkembangan, yaitu sebagai berikut: 1) Perkembangan dipengaruhi oleh faktor-faktor pembawaan, lingkungan dan kematangan; 2) Proses perkembangan itu berlangsung secara bertahap (progresif dan sistematik); 3) Bagian-bagian dari fungsi-fungsi organisme mempunyai garis perkembangan dan tingkat kematangan masing-masing; 4) Terdapat variasi dalam tempo dan irama perkembangan antar-individual dan kelompok tertentu (menurut latar belakang jenis, geografis, dan kultural); 5) Proses perkembangan itu pada taraf awalnya lebih bersifat diferensiasi dan pada akirnya lebih bersifat integrasi antar bagian dan fungsi organisme; 6) Dalam batas-batas masa peka, perkembangan atau pertumbuhan dapat dipercepat atau diperlambat oleh kondisi lingkungan; 7) Laju perkembangan anak berlangsung lebih cepat pada periode kanak-kanak daripada periode-operiode berikutnya.

Adanya keterkaitan antara belajar dan perkembangan sehingga terjadilah implikasi prinsip perkembangan terhadap pendidikan, diantaranya implikasi terhadap perkembangan biologis dan perseptual, perkembangan intelektual, perkembangan bahasa, perkembangan kreatifitas, perkembangan sosial, perkembangan emosional, perkembangan moral dan perkembangan spritual. Dengan demikian, dengan adanya ciri-ciri perkembangan yang diatur dalam prinsip (hukum) perkembangan tersebut, maka selaku kepala sekolah atau guru haruslah menyesuaikan program pembelajaran berdasarkan tahapan perkembangan peserta didik.

\section{DAFTAR PUSTAKA}

Ahmad. (1993). Psikologi Pendidikan. Bandung: Angkasa.

Hasbullah. (2009). Dasar-Dasar Ilmu Pendidikan. Jakarta: Rajawali Pers.

Kasiram, M. (1993). Ilmu Jiwa Perkembangan. Surabaya: Usaha Nasional.

Sunarto dan Hartono, Agung. (2013). Perkembangan Peserta Didik. Jakarta: Rineka Cipta.

Syamsuddin, M. A. (2004). Psikologi Kependidikan. Bandung: Remaja Rosdakarya.

Winkel, S.J., WS. (2005). Psikologi Pengajaran. Yogyakarta: Media Abadi. 